\title{
EKSPLORASI DAN IDENTIFIKASI Trichoderma sp LOKAL DARI RIZOSFER BAMBU DENGAN METODE PERANGKAP MEDIA NASI
}

\author{
Nurliana $^{1}$, Novita Anggraini ${ }^{1}$ \\ Email: fizzah.2014@gmail.com \\ ${ }^{1}$ Budiaya Pertanian, Fakultas Pertanian, Universitas Nahdlatul Ulama Sumatera Utara, Jl. \\ H. A.Manaf Lubis No.2, Gaperta Ujung, Medan Helvetia, 20215

\begin{abstract}
ABSTRAK
Penelitian ini bertujuan untuk menemukan Trichoderma sp asal dari rizosfer bambu dengan metode perangkap media nasi agar dapat diadopsi oleh petani berdasarkan sumberdaya lokal yang ada. Eksplorasi ini dilakukan di 3 (tiga) lokasi berdasarkan ketinggian tempat yaitu ketinggian 0-500 mdpl di Kecamatan Beringin Kabupaten Deli Serdang, 500-1000 mdpl di Kecamatan Bandar Pulau Kabupaten Asahan, dan > 1.000 mdpl di Kabupaten Pakpak Barat. Adapun kegiatan penelitian yang dilakukan adalah eksplorasi, isolasi, dan identifikasi dengan menggunakan metode perangkap media nasi. Hasil penelitian di ketiga daerah tersebut pada kecamatan Beringin tidak ditemukan jamur Trichoderma, di Kecamatan Bandar Pulau ditemukan 2 Jenis Trichoderma, dan di kabupaten Pakpak Barat ditemukan 1 Jenis Trichoderma sp. Trichoderma yang didapat dari kedua ketinggian tersebut memiliki kemiripan dari hasil mikroskopisnya. Diharapkan metode ini dapat diaplikasikan ke petani nantinya.
\end{abstract}

Kata Kunci: Trichoderma sp, perangkap media nasi, rizosfer bambu

\section{PENDAHULUAN}

Jamur Trichodema sp. dapat digunakan sebagai agensia hayati yang efektif mengendalikan berbagai penyakit tanaman. Salah satu spesies Trichoderma adalah T.harzianum yang dapat ditemukan hampir di semua jenis tanah dan di berbagai habitat. Trichoderma tumbuh sangat baik dan berlimpah di dalam tanah di sekitar perakaran yang sehat. $T$. harzianum menghasilkan antibiotik yang bersifat mengambat perkecambahan spora jamur (Murkalina et al. 2010).

Dalam mikrobiologi media yang digunakan untuk pertumbuhan jamur dan bakteri yaitu Potatoes Dextrose Agar (PDA) dimana salah satu komposisi nutrisi didalamnya adalah karbohidrat. Nasi juga mengandung karbohidrat sangat tinggi seperti yang diteliti oleh Puspowidowati (2011), nasi putih memiliki kadar glukosa sebesar $31,76 \%$ sedangkan nasi jagung memiliki kadar glukosa sebesar 42,28\%. Sangat memungkinkan untuk pertumbuhan jamur dan bakteri.

Indigenous knowledge yang dimiliki oleh petani yaitu belajar dari alam. Bambu merupakan tanaman yang hampir tidak pernah terserang oleh penyakit. Analisis alami yang dimiliki petani menyimpulkan tanah di sekitar bambu baik untuk pertumbuhan tanaman lain. Petani sangat sering menggunakan tanah humus dan tanah di sekitar perakaran bambu sebagai media untuk penyemaian benih tanaman.

Sampai saat ini banyak laporan yang mengatakan bahwa tanah asal rizosfer bambu banyak tumbuh jamur dan bakteri antagonis yang dapat menekan pertumbuhan pathogen. Dalam penelitian (Susanti 2015), tanah Rizosfer bambu mampu menekan pertumbuhan pathogen $P$. Palmivora penyebab penyakit busuk pangkal batang (damping off) dan meningkatkan pertumbuhan tanaman 
pepaya. Cendawan asal rizosper bambu yakni Paecilomyces sp dapat mengendalikan penyakit akar gada pada tanaman brokoli hingga $18,75 \%$ dan dapat meningkatkan pertumbuhan tanaman brokoli Dalam (Asniah et al. 2015).

Mikroba asal rizosfer bambu memiliki keragaman mikroba yang tinggi. Dibandingkan tanah non rizosfer bambu, tanah rizosfer bambu memiliki kemampuan yang lebih baik dalam meningkatkan pertumbuhan tanaman dan menekan patogen tanaman. Sifat biologi tanah rizosfer bambu yang berkaitan meliputi: tingginya total bakteri dan mikroba fungsional (bakteri kitinolitik, bakteri penambat N2), tingginya IAA total tanah dan jumlah mikroba antibiosis (Susanti 2015).

Penelitian ini bertujuan untuk memperoleh Trichoderma sp asal rizosfer bambu dengan metode perangkap media nasi.

\section{BAHAN DAN METODE}

Penelitian ini dilakukan pada bulan Maret 2018 sampai dengan bulan Juli 2018 di Lapangan dan di Laboratorium Penyakit Universitas Sumatera Utara (USU). Penelitian dilakukan terdiri dari tahapan: (1) Eksplorasi, (2) Isolasi, (3) Identifikasi secara makroskopis dan mikroskopis.

\section{Persiapan media perangkap cendawan Trichoderma sp}

Untuk setiap lokasi menggunakan 100 gr beras dicuci bersih, setelah air mendidih masukkan beras dan biarkan selama 5 menit. Angkat beras dan tiriskan. Kemudian dikukus selama 30 menit.lalu didinginkan, setelah itu masukkan ke dalam plastic ukuran $1 / 4 \mathrm{~kg}$ dan pada salah satu sisi dilubangi dengan tusuk gigi. Gali lubang sedalam $20 \mathrm{~cm}$ jarak dari tanaman bambu $5-10 \mathrm{~cm}$. Setelah itu masukkan media yang telah dipersiapkan sebelumnya dengan sisi yang diberi lubang letak dibagian bawah secara mendatar. Tutup dengan potongan bambu, kemudian ditutup kembali dengan plastik dengan rapat. Setelah 4 hari media perangkap Trichoderma sp dibongkar dan didiamkan selama 1 minggu dengan suhu ruang. Setelah itu cendawan Trichoderma sp yang terperangkap dibawa ke Laboratorium untuk dilakukan pemurnian.

Uji Mikroskopis juga dilakukan untuk masing-masing cendawan Trichoderma sp. Petridish bagian dasarnya dilapisi tissue dan diberi air supaya lembab. Kemudian di atas tissue diberi penyangga berupa stick sebanyak 2 buah. Di atas stick tersebut diletakkan slide glass. Setelah itu diatas slide glass diletakan potong inokulan dengan menggunakan cork borer dari masingmasing cendawan. Diinkubasi selama 7 hari pada suhu $27^{\circ} \mathrm{C}$. Setelah itu dilihat di bawah mikroskop untuk melihat morfologi dari Trichoderma sp.

\section{HASIL DAN PEMBAHASAN}

Hasil eksplorasi Trichoderma sp. asal Rizosfer bambu dengan media perangkap nasi dapat dilihat pada Gambar 1 dimana terlihat warna khas dari Trichoderma sp. yaitu hijau. Dalam Prabowo et al. (2006) bahwa Trichoderma sp. termasuk cendawan yang mudah tumbuh pada berbagai habitat dan lingkungan. Salah satu media agar yang cocok dan mendukung pertumbuhan jamur adalah PDA (potato dextrose agar) yang memiliki $\mathrm{pH}$ yang rendah $(\mathrm{pH} 4,5$ sampai 5,6 ) sehingga menghambat pertumbuhan bakteri yang membutuhkan lingkungan yang netral dengan $\mathrm{pH} 7,0$, dan suhu optimum untuk pertumbuhan antara 25-30 ${ }^{\circ} \mathrm{C}$ (Cappucino 2014). Menurut Bambang et al. (2008), pH beras biasa 7,27. Trichoderma yang terperangkap pada media nasi putih merupakan Trichoderma $s p$ yang dapat berkembang pada $\mathrm{pH} \geq 7$.

Jenis-jenis Trichoderma lebih banyak ditemukan di tanah perakaran daripada di tanah non vegetasi (Nandang, 2002). Menurut Winda et al. (2015) tanah rizosfer bambu bersifat disease 
suppressive soil dalam menekan pertumbuhan pathogen $P$. palmivora penyebab busuk pangkal batang (damping off) dan meningkatkan pertumbuhan bibit papaya. Hal tersebut dipengaruhi sifat kimia tanah perakaran bambu yang terlihat dari hasil analisis sifat kimia tanah menunjukkan bahwa nilai C-organik dari beberapa Rizosfer bambu lebih tinggi dibandingkan dengan non Rizosfer bambu. Hal ini ditegaskan oleh Handoko (2014) bahwa semakin tinggi kandungan $\mathrm{C}$ organik dalam tanah, maka total populasi bakteri, cendawan, maupun populasi mikrob fungsional juga akan tinggi karena ketersediaan bahan organik terpenuhi secara optimal.

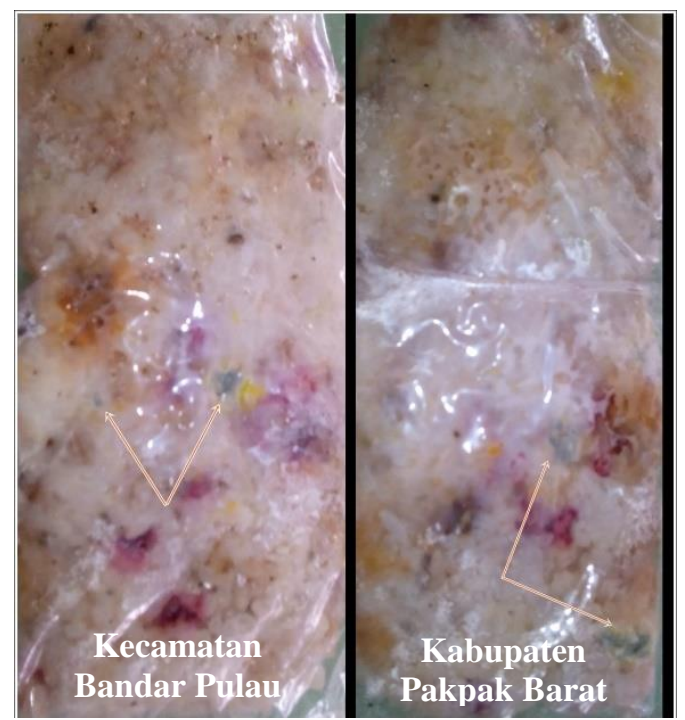

Gambar 1 Hasil eksplorasi Trichoderma sp. dengan media nasi

Mengacu pada Watanabe (2002) karakteristik Trichoderma sp dilakukan baik secara makroskopis maupun mikroskopis. Secara makroskopis meliputi warna koloni, bentuk konidia, fialid dan konidiofor (Tabel 1). Perkembangan Trichoderma memiliki persamaan (Gambar 2) yaitu yang dimulai dari warna putih, lalu hijau muda dan hijau tua setelah Trichoderma sp berumur 7 HIS dan bentuk koloni yang bulat. Perbedaan yang ditemukan pada TBP1 warna putih lebih dominan sedangkan pada TBP2 paling dominan warna hijau. Pada isolat TP1 warna putih dan warna hijau seimbang.

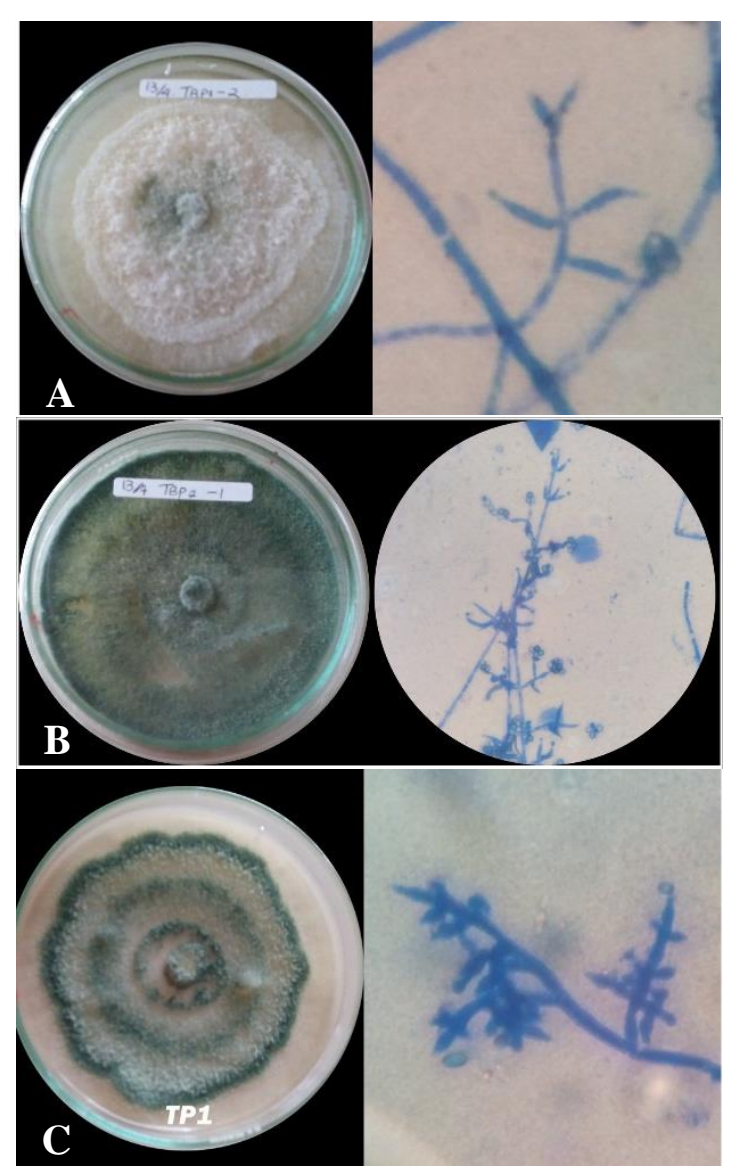

Gambar 2 (A) Trichoderma sp asal Kecamatan Bandar Pulau (TBP 1), (B) Trichoderma sp asal Kecamatan Bandar Pulau (TBP 2), (C) Trichoderma sp asal Kabupaten Pakpak Barat (TP 1)

Tabel 1 Morfologi setiap isolat yang diperoleh

\begin{tabular}{llll}
\hline \multirow{2}{*}{ Morfologi } & \multicolumn{3}{c}{ ISOLAT } \\
\cline { 2 - 4 } $\begin{array}{llll}\text { Warna } \\
\text { Koloni }\end{array}$ & $\begin{array}{l}\text { Putih hijau } \\
\text { kekuningan }\end{array}$ & Hijau gelap & $\begin{array}{l}\text { Putih hijau } \\
\text { menyerupai } \\
\text { cincin. }\end{array}$ \\
$\begin{array}{l}\text { Bentuk } \\
\text { konidium }\end{array}$ & Oval & Bulat & Bulat \\
Fialid & Seperti labu & $\begin{array}{l}\text { Seperti } \\
\text { labu }\end{array}$ & Seperti labu \\
Konidiofor & Bercabang & Bercabang & Bercabang \\
\hline
\end{tabular}

\section{KESIMPULAN}


Hasil penelitian menunjukkan bahwa di Kecamatan Beringin tidak ditemukan jamur Trichoderma sp. pada rizosfer bambu, di Kecamatan Bandar Pulau ditemukan 2 Jenis Trichoderma $s p$. (TBP1 dan TPB2), dan di Kabupaten Pakpak Barat ditemukan 1 Jenis Trichoderma sp. (TP1). Trichoderma sp. yang didapat dari kedua ketinggian tersebut memiliki kemiripan dari hasil mikroskopisnya.

\section{UCAPAN TERIMAKASIH}

Penulis mengucapkan terimakasih kepada Kementerian Riset, Teknologi dan Pendidikan Tinggi Republik Indonesia atas dana hibah yang diberikan untuk melakukan penelitian ini.

\section{DAFTAR PUSTAKA}

Asniah, Widodo, Suryo W. 2013. Potensi cendawan asal tanah perakaran bambu sebagai endofit dan agen biokontrol penyakit akar gasa pada Tanaman Brokoli. J. HPT Tropika. 13 (1): 61-68.

Handoko S. 2014. Kajian epidemi penyakit kanker batang Duku di Provinsi Jambi. [disertasi]. Yogyakarta (ID): Universitas Gadjah Mada.

Murkalina. 2010. Uji antagonis Trichoderma harzianum terhadap Fusarium spp. penyebab penyakit layu pada tanaman cabai (Capsicum annum) secara In Vitro. Jurnal Fitomedika. 7 (2): 80 - 85.

Bambang N, Heri RM, Tita R, Purawisastra S. 2008. Pengujian beras aking sebagai bahan makanan. PGM. 31(1): 15-20.

Nandang S. 2002. Keberadaan dan distribusi jenis-jenisTrichoderma di hutan kawasan Taman Nasional Gunung Halimun. Berita Biologi. 6 (1).

Prabowo AKE, Nur P, Loekas S. 2006. Potensi Trichoderma harzianum dalam mengendalikan sembilan isolat Fusarium oxysporum Schecht.f.sp. Zingiberi Trujillo pada Kencur. Jurnal Ilmu-ilmu Pertanian Indonesia. 8 (2): 76-84.

Puspowidowati A. 2011. Penentu profil gula pereduksi dari beras, jagung giling, dan jagung pipilan (suatu upaya penggalian pangan alternatif berindeks glikemik rendah bagi penderita diabetes). [thesis]. Surabaya (ID): Universitas Airlangga.

Susanti WI. 2015. Kajian Sifat Kimia dan Biologi Tanah Rizosfer Bambu sebagai Disease Suppresive Soil. [tesis]. Bogor (ID): Sekolah Pascasarjana IPB. 